PROSES KOPING RELIGIUS PADA WANITA DENGAN KANKER PAYUDARA

Zahra Devina Nurmahani

\author{
Program Studi Psikologi Fakultas Ilmu Sosial dan Humaniora \\ Universitas Islam Negeri Sunan Kalijaga Yogyakarta
}

\begin{abstract}
INTISARI
Penelitian ini menggunakan pendekatan kualitatif fenomenologis yaitu untuk memahami pengalaman yang disadari oleh responden dalam proses koping religius yang dilakukan beserta pengaruh dari koping religius dan faktor yang mempengaruhi proses koping religius tersebut. Pengumpulan data menggunakan teknik wawancara dan observasi. Responden pada penelitian ini berjumlah tiga orang wanita yang didiagnosis kanker payudara. Responden diambil berdasarkan kriteria dalam penelitian ini.

Hasil penelitian menunjukkan bahwa koping religius memiliki peran penting bagi responden dalam menghadapi kanker payudara ataupun dalam kehidupan sehari-hari. Proses koping religius dalam penelitian ini dibagi menjadi 4 fase yaitu koping religius pada fase gejala, fase diagnosis, fase pengobatan dan pada fase pemaknaan terhadap sakit. Koping religius yang dilakukan oleh responden ada yang muncul pada setiap fase meskipun ada juga beberapa koping religius yang tidak muncul lagi di fase lain. Koping religius yang banyak muncul pada fase diagnosis sampai fase pengobatan yaitu fase yaitu berdoa dan beribadah (sholat tahajud dan berdzikir), sedangkan pada fase pemaknaan terhadap sakit yaitu sakit adalah cobaan/ujian dari Allah. Pengaruh yang dirasakan dengan melakukan koping religius yaitu ketenangan, kelegaan, kepuasan, kenikmatan dalam beribadah, terkontrol emosi dan pikiran, serta merasa dipermudah dalam berbagai hal. Beberapa faktor yang mempengaruhi koping religius yaitu pengaruh (pendidikan/belajar) dari orang-orang terdekat (orang tua, suami, guru agama), penghayatan dari pengalaman hidup, penghayatan dan pengalaman atas kegiatan keagamaan dan ibadah yang dilakukan, dan budaya.
\end{abstract}

Kata kunci : Koping Religius, Wanita Kanker Payudara 


\title{
PROCESS OF RELIGIOUS COPING IN WOMEN WITH BREAST CANCER
}

\section{Zahra Devina Nurmahani \\ 12710070}

Psychology of Sunan Kalijaga Islamic State University of Yogyakarta

\begin{abstract}
The study's main purpose was to describe how process religious coping in women with breast cancer. Religious coping is effort of someone with the involve religious elements for cope internal or extrenal pressure. Women with the breast cancer is women with growth of cells or tissues that are not controlled so that the growth of abnormal cells, rapid, and immortal.

This study uses a phenomenological qualitative approach is to understand the experiences realized by the respondent in the process of religious coping were carried along with the influence of religious coping and the factors that affect the process of religious coping. Collecting data using interview and observation techniques. Respondents in this study were three women diagnosed with breast cancer. Respondents were drawn based on the criteria in this study.

The results showed that religious coping has an important role for respondents in the face of breast cancer or in everyday life. The process of religious coping in this study were divided into 4 phases which religious coping in phase symptoms, diagnosis phase, treatment phase and the phase of meaning to the illness. Religious coping performed by respondents that appear in every phase although there are also some religious coping that do not appear again in another phase. Religious coping that have appeared in the diagnosis phase to the treatment phase is the phase of prayer and ibadah (tahajud prayer and dhikr), while the phase of meaning to pain that pain is a trial / test from God. The influence is felt by religious coping is tranquility, relief, satisfaction, pleasure in ibadah, uncontrolled emotions and thoughts, and feel easy in many ways. Some of the factors that affect religious coping is the influence (education / learning) of those closest (parents, husbands, teachers of religion), appreciation of life experiences, appreciation and experience of religious activities and ibadah and culture.
\end{abstract}

Key Words : Process of Religious Coping, Women with breast cancer. 


\section{PENDAHULUAN}

$\mathrm{P}$ enyakit kanker merupakan salah satu penyebab kematian utama di dunia setelah kardiovaskular. Kanker menjadi penyebab kematian 8,2 juta jiwa di dunia pada tahun 2012 (Kemenkes RI, 2015). Menurut WHO (Word Health Organization) lebih dari $70 \%$ kematian yang terjadi di negara miskin dan berkembang disebabkan oleh kanker (Kemenkes RI, 2015). Kanker dengan persentase kasus baru tertinggi (setelah dikontrol dengan umur) terdapat pada kanker payudara yaitu sebesar 43,3\%. Kanker payudara ini merupakan penyebab kematian tertinggi akibat kanker. Pada perempuan kanker payudara menyebabkan kematian sebesar 12,9\% (Kemenkes RI, 2015).

Pada tahun 2013 estimasi kejadian kanker payudara di Indonesia sebesar 40 per 100.000 perempuan. Jumlah ini meningkat dibandingkan tahun 2002, dimana estimasi kejadian kanker payudara sebanyak 26 per 100.000 perempuan. Jenis kanker tertinggi pada pasien rawat inap di rumah sakit di seluruh Indonesia pada tahun 2010 adalah kanker payudara (28,7\%), lalu kanker serviks (12,7\%) (Kemenkes RI, 2015).

Kanker yang masuk pada kategori penyakit kronis dan bahkan juga terminal dapat menimbulkan beberapa permasalahan pada pasien atau orang dengan kanker. Permasalahan tersebut seperti masalah medis, sosial dan psikologis, dimana hal tersebut membatasi aktivitas pasien sehingga akan menurunkan kualitas hidup pasien (Yenny \& Herwana, 2006). Damayanti, Fitriyah \& Indriani (2008) juga mengatakan bahwa seseorang dengan penyakit terminal seperti kanker dapat mengalami masalah psikologis dan sosial selain menghadapi masalah fisik.

Permasalahan medis pada orang/pasien dengan penyakit kronis atau terminal termasuk kanker payudara yaitu yang berhubungan dengan gangguan fungsi pada organisme yang sakit (patofisiologi). Patofisiologi ini meliputi asal penyakit, permulaan perjalanan penyakit dan akibat dari penyakit. Sedangkan permasalahan sosial pada orang dengan kanker payudara misalnya yaitu permasalahan dalam interaksi sosial seperti pergaulan yang terbatas karena menarik diri dari keluarga atau teman. Permasalahan medis dan sosial yangdihadapi orang dengan penyakit kanker termasuk kanker payudara akan mempengaruhi kondisi psikologis. Penyakit yang dialami oleh individu akan mempengaruhi emosi, penampilan dan perilaku sosial individu tersebut. 
Kondisi psikologis yang muncul karena penyakit juga akan mempengaruhi kesehatan fisik dari individu tersebut. Hal ini menjelaskan bahwa permasalahan medis, sosial dan psikologis akan saling mempengaruhi satu sama lain (Charles \& Ashman dalam Damayanti, Fitriyah, \& Indriyani, 2008).

Penelitian yang dilakukan oleh Oetami, Thaha, \& Wahiduddin (2014) menunjukkan bahwa dampak psikologis yang dialami penderita kanker dapat berbeda-beda. Hal tersebut disebabkan diantaranya oleh tingkat keparahan (stadium), dan jenis pengobatan yang dijalani. Sekitar 30\% penderita mengalami permasalahan penyesuaian diri, dan $20 \%$ mengalami depresi. Dampak psikologis penderita kanker dapat berupa ketidakberdayaan, kecemasan, rasa malu, harga diri menurun, stress, dan marah.

Hidup dengan suatu penyakit yang berla ngsung lama maupun bersifat terminal membuat penderitanya sangat tidak nyaman. Proses adaptasi atas ketidaknyamanan ini dapat memberikan pengaruh yang tidak baik (tidak adaptif). Kegagalan seseorang dalam menyesuaikan diri dengan penyakit mengakibatkan koping yang tidak adaptif dengan berbagai dampak seperti ketidakpuasan, kecemasan, perasaan tidak berdaya dan depresi, dimana semua hal tersebut memiliki efek yang tidak baik terhadap penyakit seperti kematian ataupun kualitas hidup orang tersebut (Farcas \& Nastasa, 2011).

Seberapa baik penderita kanker melakukan adaptasi dengan kanker dapat memberikan dampak kemajuan terhadap penyakit. Seseorang memiliki tingkat ketidakberdayaan yang tinggi, depresi, dan mudah terserang masalah psikososial ditemukan bertahan hidup lebih singkat setelah diagnosis kanker. Adaptasi yang dilakukan oleh penderita kanker tergantung dari beberapa aspek dari penyakit dan situasi psikososial. Penderita kanker yang cenderung mengalami depresi paling berat adalah yang mengalami kecacatan. Selain itu penderita kanker yang mengalami depresi setiap waktu akibat diagnosis dilaporkan memiliki kualitas hidup yang rendah diantara survivor kanker (Sarafino \& Smith, 2012). Berhubungan dengan permasalahan yang dihadapi oleh pasien atau orang dengan penyakit kronis termasuk kanker payudara, berbagai intervensi yang dilakukan harus mencakup segala aspek dari permasalahan baik medis, sosial dan psikologis atau dengan kata lain perawatan pada pasien kanker harus dilakukan secara holistik bukan hanya terkait fisiknya saja. Pasien 
membutuhkan sumber internal maupun sosial untuk mengatasi, meringankan dan mengurangi permasalahan psikologis (Taylor, 2006). Berbagai aspek dukungan dibutuhkan oleh pasien seperti dukungan sosial baik dari keluarga maupun dari lingkungan sosial, dukungan dari tenaga kesehatan, kebutuhan akan informasi penyakit, kebutuhan instrument, dan juga kebutuhan spiritual (Widianti, Suryani, \& Puspasari, 2014). Intervensi biomedical yang dijalani oleh pasien kanker payudara seperti operasi, radioterapi maupun kemoterapi, juga harus didukung dengan penanganan masalah psikologisnya seperti mengurangi pikiran negatif, meningkatkan pikiran positif dan meningkatkan koping (Forshaw, 2009). Banyak penelitian yang menunjukkan bahwa spiritualitas atau agama memainkan peran penting pada proses koping terutama bagi pasien yang menghadapi penyakit parah dan mengancam (Gall \& Maclean dalam Zwingmann, Wirtz, Muller, Korber, \& Murken, 2006). Hal ini juga didukung dengan banyaknya ahli klinis yang mengakui pentingnya agama dan spiritualitas terhadap gangguan fisik maupun psikologis seseorang. Agama dan spiritualitas dipercaya dan dipraktekkan dapat memainkan peran terhadap serangan stress dan koping karena adanya suatu penyakit (Manhaee \& Amini, 2013).

Kekuatan agama terletak pada keberfungsian agama dalam menawarkan berbagai metode koping dengan berbagai situasi (Pargament, Koenig, \& Perez, 2000). Agama merupakan fenomena multifungsi yang banyak melayani fungsi individu dan sosial. Tiga dimensi utama dari agama yang memenuhi kebutuhan manusia mungkin terletak pada kebutuhan manusia akan makna (need for meaning), kebutuhan akan kontrol (need for control), dan kebutuhan akan keterhubungan dengan orang lain (need for relationship). Tiga hal tersebut didasarkan pada asumsi bahwa pencarian makna sangat penting untuk keberfungsian manusia dan agama mampu menfasilitasi hal tersebut. Agama merupakan sistem makna global yang penting bagi banyak orang karena memberikan serangkaian keyakinan, tujuan, dan makna di mana hal ini digunakan termasuk saat berhubungan dengan situasi atau permasalahan yang dihadapi individu (Krok, 2014). Agama yang merupakan sumber nilai, kepercayaan, dan pola-pola tingkah laku yang akan memberikan tuntutan bagi arti, tujuan dan kestabilan manusia (Muslimah \& Aliyah, 2013). 
Berhubungan dengan agama dan koping, Pargament menyatakan bahwa agama menjadi bagian sentral dari konstruksi koping. Agama memiliki dua arah peran sebagai bagian dari proses koping transaksional, yang pertama agama menyumbang proses koping dan kegiatan koping dalam menghadapi peristiwa dalam hidup. ke dua agama menjadi hasil koping yang dibentuk oleh elemen- elemen lain yang berproses (dalam Utami, 2012).

Koping menurut Lazarus dan Folkman (dalam Rice, 2011) yaitu merubah secara konstan usaha kognitif dan perilaku untuk mengatur tuntutan spesifik internal dan atau eksternal yang dinilai membebani atau melampaui sumber daya yang dimiliki seseorang. Berdasarkan definisi tersebut terlihat bahwa usaha yang dilakukan untuk mengatasi fenomena itu berorientasi pada proses, bukan pada suatu sifat atau hasil, dan jelas bahwa upaya tersebut berbeda dari perilaku adaptif otomatis yang telah dipelajari. Koping tidak selalu berarti penguasaan atas ketidaknyamanan atau stress, tetapi juga bisa pengelolaan, misalnya seperti meminimalkan, menghindari, mentolerir, merubah, atau menerima situasi tertentu sebagaimana seseorang yang mencoba untuk menguasai atau menangani lingkungannya.
Pargament

(1997)

mendefinisikan koping religius sebagai strategi koping yang melibatkan agama dalam menyelesaikan masalah dengan meningkatkan ritual keagamaan (dalam Muslimah \& Aliyah, 2013). Sedangkan menurut Juniary

\& Hadjam (2012) koping religius merupakan proses multidimensional guna mengelola, menguasai atau mengubah situasi, mengatur respon emosional, atau percampuran dari perilaku tersebut dengan menggabungkan sumber daya rohani baik personal maupun sosial, proses penilaian dengan makna suci, ataupun hasil dari pemilihan koping yang mengakui pencarian kesu cian dari ajaran agama yang dianut. Koping religius mencakup berbagai bentuk spesifik yang bervariasi dari koping mulai dari bentuk aktif sampai bentuk pasif, dari bentuk problem-focus ataupun emotional-focus, dari bentuk positif ataupun negatif. Selain itu cakupan koping religius juga meliputi kognitif-behavioral sampai interpersonal dan spiritual. (Pargament dalam Simonic \& Klobucar, 2016).

Menurut Pargament (1997) strategi koping religius berhubungan dengan tingkat kompetensi untuk menyelesaikan suatu permasalahan yang tinggi. Berdasarkan tingkat personal, orang-orang yang menggunakan 
strategi koping religius adalah yang memiliki keterlibatan dan komitmen dengan agama, biasanya orang dengan tingkat ekonomi menengah kebawah, wanita, lansia, dan orang yang memiliki masalah serius. Selain itu koping religius sering terjadi pada situasi yang lebih mengancam dan membahayakan pada tingkat situasional. Berdasarkan tingkat kontekstual koping religius lebih banyak terjadi pada orang-orang yang terlibat dalam aktivitas religius dan pada lingkungan perkumpulan keagamaan (dalam Muslimah \& Aliyah, 2013).

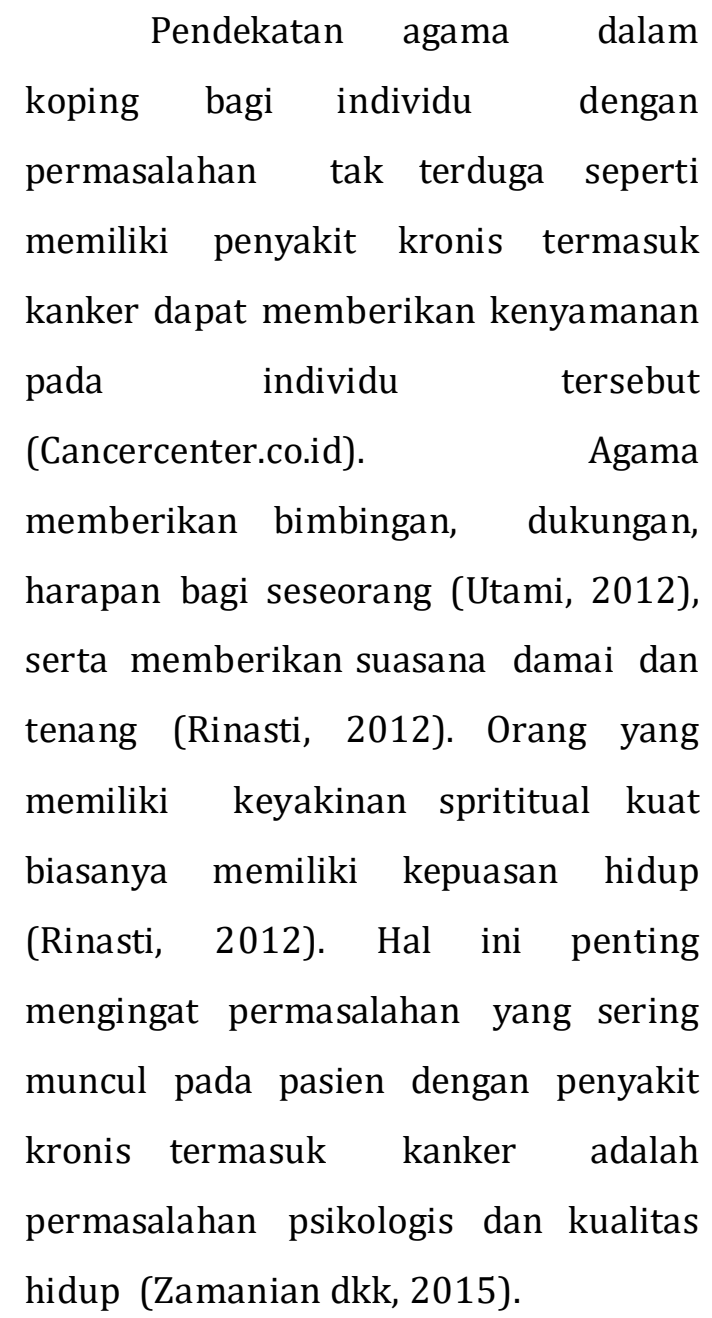

Praktek religius seperti berdoa (sholat) dan meditasi dapat meningkatkan rasa kontrol terhadap kejadian yang penuh stress. Agama memberikan rasa akan tujuan dan kebermaknaan untuk peristiwa yang tidak dapat dipahami/tak terduga ataupun sakit kronis. Keyakinan religius dapat memberikan kerangka untuk memahami kematian. Agama mengajak seseorang yang memiliki suatu penyakit untuk menerima penyakitnya (Tarakeshwar dkk, 2006).

Selain berdampak terhadap psikologis penderita kanker, koping religius juga berdampak pada kesehatan fisiologis. Koenig (dalam Safaria, 2011) menjelaskan hubungan antara agama, religiusitas dan kesehatan fisik serta psikologis. Penjabarannya yaitu agama akan membentuk sebuah makna ketika individu berhadapan dengan suatu permasalahan dan hidupnya dengan membuat sebuah cara pandang umum yang positif dengan keyakinan bahwa Tuhan akan membantu seorang hamba yang berada dalam kesulitan. Keyakinan tersebut akan membentuk rasa optimis. Orang yang lebih religius akan lebih mampu menginterpretasikan pengalaman hidup negatif dengan cara pandang positif dan penuh hikmah. Adanya pandangan positif tersebut akan tumbuh sebuah harapan yang 
selanjutnya akan menumbuhkan ketenangan dan menghindarkan dari keadaan distress dan depresi.

Pargament menjelaskan bahwa koping religius merupakan konstruk multidimensional dimana ada yang positif dan negatif. Koping religius positif mencerminkan hubungan yang aman dengan Tuhan, sedangkan koping religius negatif menggambarkan hubungan ekspresi yang kurang aman dengan Tuhan. Kebanyakan penelitian hanya berfokus pada dimensi positif. Seseorang yang menginterpretasikan suatu masalah yang menimpa dengan interpretasi yang negatif seperti hukuman mungkin akan membuat usaha yang tidak efektif untuk berdamai dengan situasi stres (Pargament, Koenig, \& Perez, 2000). Pada metode koping religius positif seperti berdoa dan penilaian agama yang baik ketika dalam situasi negatif, selain mencerminkan persepsi ada hubungan yang aman dengan Tuhan, juga mencerminkan keyakinan akan tujuan hidup yang baik, serta rasa keterhubungan dengan komunitas keagamaan. Sedangkan pada metode koping religius negatif selain mengatribusikan hukuman dan perasaan ditinggal oleh Tuhan, juga mencerminkan hubungan yang renggang dengan Tuhan, dan tidak adanya keterhubungan dengan kelompok keagamaan (Tarakeshwar dkk, 2006). Koping religius negatif memiliki dampak buruk pada kualitas hidup (Zamanian dkk, 2015; Pearce, Singer, \& Prigerson, 2006).

Penelitian yang dilakukan oleh Zwingmann, Wirtz, Muller, Korber, \& Murken (2006) pada 156 penderita kanker payudara di German, ditemukan bahwa koping religius positif banyak digunakan. Hasil penelitian yang dilakukan oleh Zamanian dkk (2015) pada 224 penderita kanker payudara di Irak juga memperlihatkan bahwa koping religius positif juga banyak digunakan dari pada koping religius negatif. Selain itu pada penderita kanker stadium lanjut yang berjumlah 170 pasien dilaporkan bahwa pasien yang banyak menggunakan koping religius positif yaitu pasien wanita (Tarakeshwar dkk, 2006).

Bagi pasien yang memiliki suatu penyakit yang mengancam seperti kanker, agama dan koping religius positif menjadi faktor penting yang mempengaruhi kualitas hidup mereka. Studi mengenai psikospiritual yang dilakukan pada pasien kanker ditemukan bahwa mereka mengalami kemajuan well-being yang dipengaruhi oleh spiritual atau agama yaitu kesadaran diri (self-awareness), koping dan penyesuaian yang efektif terhadap stress, hubungan dan keterhubungan 
dengan yang lain, rasa akan iman (sense of faith), rasa akan berdaya (sense of empowerment), kepercayaan diri dan hidup dengan makna dan harapan (Tarakeshwar dkk, 2006). Koping religius positif pada pasien kanker payudara terminal dapat membuat kualitas hidupnya lebih baik. Sebaliknya, koping religius negatif akan membuat kualitas hidup pasien semakin buruk (Zamanian dkk, 2015; Pearce, Singer, \& Prigerson, 2006). Selain itu koping religius negatif juga menaikan gangguan kecemasan dan gangguan depresif mayor (Pearce, Singer, \& Prigerson, 2006). Hal ini menunjukkan bahwa sangat penting adanya dukungan akan psycho-religius pada pasien (Zamanian dkk, 2015;
Pearce, Singer, \& Prigerson, 2006). Oleh Karena itu, penelitian ini bertujuan untuk mengetahui proses koping religius pada wanita dengan kanker payudara.

\section{METODE PENELITIAN}

Peneliti menggunakan jenis penelitian kualitatif dengan pendekatan fenomenologi dan pengumpulan data dilakukan menggunakan teknik wawancara , observasi serta dokumentasi. Responden dalam penelitian ini berjumlah 3 orang dengan kriteria wanita yang di diagnosis kanker payudara dan berusia 30 tahun ke atas. Data yang dikumpulkan berupa profil umum responden, proses koping religius dan faktor-faktor yang mempengaruhi proses koping religious.

\section{Subjek}

Tabel 1. Data diri responden

\begin{tabular}{lcccc}
\hline No & Inisial & Alamat & Usia & \multicolumn{2}{c}{ Diagnosa } \\
\hline 1 & DA & Gunungwungkal & 56 tahun & Malignant neoplasm \\
& & of & breast, \\
& & unspecified-C50.9 \\
\hline 2 & OK & Kota Pati & 60 tahun & Carcinoma in situ of \\
& & & breast, unspecified- \\
& & & D05.9 \\
\hline 3 & YN & Kota Pati & 44 tahun & Malignant neoplasm \\
& & & of \\
& & & breast, \\
& & & unspecified-C50.9 \\
\hline
\end{tabular}




Hasil
Peneliti membahas proses
koping religius melalui analisis tema
-tema. Peneliti membagi proses koping
religius pada setiap responden
menjadi 4 fase yaitu : 1 ) fase
munculnya gejala kanker payudara; 2)
fase diagnosis kanker payudara; 3)
fase pengobatan kanker payudara; 4)
fase pemaknaan terhadap sakit.

\section{Hasil}

Selain proses koping religius, dampak koping religius dan faktor yang mempengaruhi koping religius juga dibahas dalam bentuk tema-tema. 
Tabel 2. Tema proses koping religius, dampak koping religius, dan pengaruh koping religius.

\begin{tabular}{|c|c|c|c|c|c|c|c|}
\hline & & Tema & DA & Tema & $\mathrm{OK}$ & Tema & YN \\
\hline \multirow[t]{6}{*}{$\begin{array}{l}\text { Proses } \\
\text { Koping } \\
\text { Religius }\end{array}$} & \multirow[t]{2}{*}{$\begin{array}{l}\text { Fase gejala } \\
\text { kanker }\end{array}$} & 1 & $\begin{array}{l}\text { Rutin hadir dalam pengajian } \\
\text { dan berwudhu hilangkan } \\
\text { stress }\end{array}$ & \multirow[t]{2}{*}{1} & \multirow{2}{*}{$\begin{array}{l}\text { Berdoa untuk mengurangi } \\
\text { kecemasan akibat munculnya } \\
\text { benjolan dan payudara yang } \\
\text { membengkak }\end{array}$} & \multirow[t]{2}{*}{1} & \multirow[t]{2}{*}{$\begin{array}{l}\text { Doa untuk mengurangi } \\
\text { kekhawatiran terhadap benjolan dan } \\
\text { rasa takut menghadapi biopsy }\end{array}$} \\
\hline & & 2 & $\begin{array}{l}\text { Menghadapi segala peristiwa } \\
\text { hidup denga berdoa, sholat } \\
\text { tahajud dan dzikir (membaca } \\
\text { sholawat }\end{array}$ & & & & \\
\hline & $\begin{array}{l}\text { Fase } \\
\text { diagnosis } \\
\text { kanker }\end{array}$ & 3 & $\begin{array}{l}\text { Mencari kenyamanan dengan } \\
\text { berpasrah, sabar, dan berdoa } \\
\text { dalam menghadapi diagnosis } \\
\text { kanker }\end{array}$ & 2 & 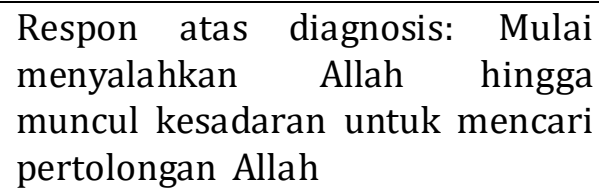 & 2 & $\begin{array}{l}\text { Menerima diagnosis kanker yang } \\
\text { mengejutkan, berdoa untuk } \\
\text { menghadapi pengobatan }\end{array}$ \\
\hline & $\begin{array}{l}\text { Fase } \\
\text { pengobata } \\
\text { n kanker }\end{array}$ & 4 & $\begin{array}{lcc}\text { Mencari dan } & \text { menerima } \\
\text { dukungan dari orang lain } \\
\text { termasuk dukungan spiritual }\end{array}$ & 3 & \begin{tabular}{lrr} 
Menyikapi & \multicolumn{3}{c}{ ketidakberdayaan } \\
dengan pasrah dan lebih \\
mendekatkan diri dengan & Allah \\
(berdoa, sholat tahajud, dan \\
dzikir)
\end{tabular} & 3 & $\begin{array}{l}\text { Yakin kepada Allah dan beribadah } \\
\text { dalam menghadapi penyakit kanker } \\
\text { (berdoa dan berdzikir, serta } \\
\text { melakukan tahajud meskipun tidak } \\
\text { rutin) }\end{array}$ \\
\hline & & 5 & $\begin{array}{lr}\text { Istiqomah } & \text { dan } \\
\text { memaksimalkan diri dalam } \\
\text { beribadah (berdoa, sholat } \\
\text { tahajud, dzikir, dan menjaga } \\
\text { wudhu) }\end{array}$ & 4 & $\begin{array}{l}\text { Bersyukur karena merasa } \\
\text { dipermudah dalam segala hal }\end{array}$ & & \\
\hline & $\begin{array}{l}\text { Fase } \\
\text { pemaknaan } \\
\text { terhadap }\end{array}$ & 6 & $\begin{array}{l}\text { Sakit merupakan cobaan dan } \\
\text { ganjaran atas hidup yang } \\
\text { telah dijalani }\end{array}$ & 5 & $\begin{array}{l}\text { Sakit merupakan ujian Allah dan } \\
\text { membawa lebih khusyuk dalam } \\
\text { beribadah }\end{array}$ & 4 & $\begin{array}{l}\text { Kanker merupakan cobaan dan } \\
\text { peringatan Allah, bersyukur dapat } \\
\text { mengetahui kanker lebih awal }\end{array}$ \\
\hline Dampak & oping Religius & 1 & Manfaat yang besar dari & 1 & Hati dan emosi terjaga dengan & 1 & Ibadah membawa ketenangan dan \\
\hline
\end{tabular}




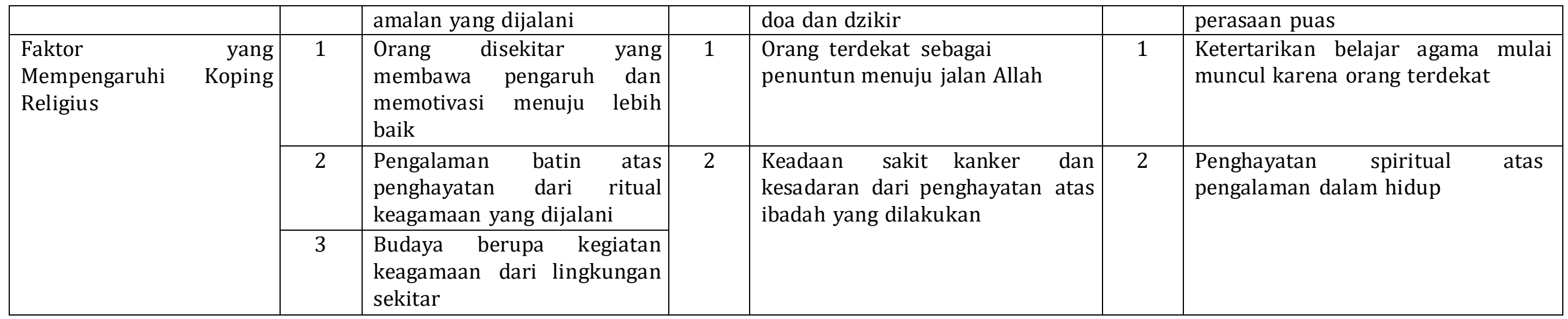


Proses Koping Religius

1. Fase Gejala Kanker payudara

Responden DA

Tema 1: Rutin hadir dalam pengajian dan berwudhu untuk menghilangkan stress

Menghadiri pengajian sudah menjadi rutinitas DA sebelum sakit kanker payudara ataupun ketika DA mulai menyadari benjolan di payudara. DA hanya membiarkan benjolan tersebut tanpa memeriksakan ke dokter meskipun ada sedikit kekhawatiran. DA menyadari benjolan di payudara semakin membesar beberapa minggu setelah kematian suaminya. DA mengatasi stres akibat kematian suami dan benjolan di payudara yang semakin membesar dengan tetap mengikuti kegiatan pengajian yang sering digelar di daerah DA, dimana DA dapat bertemu dengan teman-teman, melupakan sejenak permasalahan yang dihadapi, dan mendapat pencerahan dengan mendengarkan ceramah dan berdoa bersama kyai. Selain rutin mengikuti pengajian, DA mengaku sering berwudhu ketika memiliki banyak pikiran dan tertekan.

Tema 2 : Menghadapi segala peristiwa hidup dengan berdoa, sholat tahajud, dan dzikir (membaca sholawat)

Benjolan di payudara yang terkadang menimbulkan rasa nyeri membuat DA bertambah khawatir. DA hanya mengusahakan kesembuhan dengan berobat alternatif, dan dengan melanjutkan rutinitas amalan yang selalu dilakukan DA sehari-hari yaitu berdoa, tahajud, dan memperbanyak membaca sholawat. Suatu ketika DA mengalami kecelakaan terjatuh dari motor dan membuat benjolan di payudara pecah. Setelah kejadian terjatuh kondisi DA semakin memburuk, akhirnya setelah diobati di puskesmas dan bidan desa tidak ada perubahan yang baik, akhirnya DA dibawa ke rumah sakit barulah diketahui oleh keluarga bahwa DA memiliki sakit kanker payudara dan harus dirujuk ke rumah sakit yang lebih besar. DA menolak untuk melakukan rujukan berobat. Selama di rumah sakit DA hanya dapat berdzikir untuk menenangkan pikiran dan hati.

\section{Responden OK}

Tema 1 : Berdoa untuk mengurangi kecemasan akibat munculnya benjolan dan payudara yang membengkak

OK menyadari benjolan di bagian ketiak saat mandi. OK yang sudah mengetahui mengenai gejala kanker payudara segera memeriksakan diri ke dokter keluarga. Dokter mengatakan bahwa benjolan tersebut merupakan kelenjar, OK diberi obat dan diminta untuk kembali seminggu kemudian 
apabila benjolan tersebut tidak hilang. Setelah seminggu benjolan tidak menghilang dan justru membengkak, namun $\mathrm{OK}$ tidak menceritakan pada suami karena takut diminta untuk periksa lagi (OK takut dengan pemeriksaan dokter seperti disuntik dan dibedah). Selama kurang lebih 6 bulan OK merahasiakan benjolan dari suami sampai akhirnya muncul keinginan dan komitmen DA untuk sembuh dengan memeriksakan benjolan ke rumah sakit. Selama beberapa bulan sebelum memeriksakan diri ke rumah sakit, OK hanya berdoa agar benjolan tersebut tidak semakin parah.

\section{Responden YN}

Tema 1 : Doa untuk mengurangi kekhawatiran terhadap benjolan yang dan rasa takut menghadapi biopsy

YN menyadari terdapat benjolan di ketiak saat mengobati herpes yang saat itu terletak di ketiak. Setelah mengadu pada suami bahwa terdapat tumor di ketiak, dua hari kemudian (Senin pagi) YN memeriksakan diri ke dokter keluarga. Dokter tersebut tidak dapat memberikan informasi ganas atau tidaknya benjolan, dan meminta YN untuk periksa ke rumah sakit. Hari itu juga YN memeriksakan diri ke rumah sakit swasta dan dokter langsung meminta YN untuk melakukan operasi biopsi. Menunggu jam operasi YN hanya pasrah dan banyak berdoa untuk keselamatan dirinya. Saat memasuki ruang operasi YN sempat menangis karena merasa takut. Setelah biopsi dilakukan, YN harus menunggu hasil laboratorium selama beberapa minggu untuk mengetahui tumor tersebut ganas atau tidak. YN menanti hasil laboratorium dengan banyak berdoa dan mempersiapkan mental mendengar hasil terburuk.

\section{Fase Diagnosis Kanker Payudara Responden DA} Tema 3 : Mencari kenyamanan dengan berpasrah, sabar dan berdoa dalam menghadapi diagnosis kanker

Mendengar diagnosis kanker payudara yang disampaikan oleh keluarga, DA sedikit terkejut dan mengungkapkan kecemasan dan ketakutan terhadap tindakan operasi serta memilih untuk menolak operasi. Informasi yang didapatkan DA terkait pengobata $\mathrm{n}$ kanker baik mengenai perjalanan yang jauh dan dampak pengobatan membuat DA bersikukuh untuk menolak pengobatan di rumah sakit. DA menghadapi rasa cemas dan takut dengan berpasrah pada Allah, bersabar, serta berdoa agar keadaan dirinya membaik. DA mengaku bersyukur atas kehidupan yang selama dijalani dan DA meyakini bahwa hidup dan mati sudah diatur oleh Alah. DA meletakkan pikiran 
dengan mengembalikan semua pada Allah.

\section{Responden OK}

Tema 2 : Respon atas diagnosis : Mulai dari menyalahkan Allah hingga muncul kesadaran untuk mencari pertolongan Allah

OK awalnya menyalahkan Allah dan berpikir Allah tidak adil atas diagnosis kanker payudara yang diterima. Saat itu DA sangat terkejut dan masih belum dapat menerima keadaan. Sempat berpikir negatif pada Allah, akhirnya timbul kesadaran dalam diri OK untuk mencari pertolongan Allah. OK menjadikan sholat ahajud sebagai tempat untuk mencurahkan isi hati, menangis dan meminta perlindungan dari Allah atas rasa takut, cemas, kesedihan dan kegundahan.

\section{Responden YN}

Tema 2 : Menerima diagnosis kanker yang mengejutkan, berdoa untuk meghadapi pengobatan kanker

Terkejut atas diagnosis kanker payudara tidak dapat dihindari oleh YN meskipun selama sebulan YN mempersiapkan diri mendengar kabar buruk dari hasil laboratorium. Diagnosis kanker membuat YN terpikir kesalahan apa yang telah diperbuat sehingga terkena kanker payudara. Namun esedihan yang dirasakan YN tidak berlangsung lama dan YN langsung dapat menerima keadaan yang sedang dihadapi. Menghadapi kenyataan yang ada YN berdoa kepada Allah untuk kelancaran pengobatan yang akan dijalani. YN memantapkan niat untuk melakukan pengobatan kanker dengan melakukan rujukan rumah sakit.

\section{Fase Pengobatan Kanker Payudara} Responden YN

Tema 4 : Mencari dan menerima dukungan dari orang lain termasuk dukungan spiritual

Selain mendapatkan dukungan oleh keluarga, DA juga mendapatkan dukungan dari teman dan tetangga. Sepulang dari rumah sakit (setelah kejadian kanker payudara pecah) banyak tetangga dan teman DA yang menejnguk. DA meminta doa dari setiap tamu yang datang menjenguk. Selain diberi dukungan psikologis dan doa, DA juga mendapatkan saran terkait obat-obat tradisional dari tamu nyang menjenguk.

Tema 5 : Istiqomah dan memaksimalkan diri dalam beribadah (berdoa, sholat tahajud, dzikir dan menjaga wudhu)

Sepulang dari rumah sakit DA memiliki banyak waktu luang karena hanya beraktivitas di dalam rumah, hal ini digunakan DA untuk lebih banyak 
beribadah pada Allah. Tidak ada yang berubah terkait rutinitas DA seperti tahajud, berdoa, dzikir da n menjaga wudhu, justru sholat tahajud menjadi sarana DA untuk memperbanyak doa agar diberi kesembuhan. Dzikir (membaca sholawat) menjadi andalan DA untuk mengisi waktu yang banyak luang misalnya sembari menonton acara TV. Sebelum berdzikir, D A biasa membukanya dengan berwudhu. Dzikir juga dilakukan DA menjelang waktu dzuhur sekaligus menunggu waktu dzuhur.

\section{Responden OK}

Tema 3 : Menyikapi ketidakberdayaan dengan pasrah dan lebih mendekatkan diri dengan Allah (berdoa, sholat tahajud, dan dzikir)

Penyesalan OK karena tidak sesegera mungkin dalam melakukan pemeriksaan setelah menyadari gejala kanker tidak menyurutkan komitmen $\mathrm{OK}$ untuk sembuh dari sakit kanker payudara. Bentuk keinginan OK untuk sembuh terlihat dari usaha OK untuk melakukan segala sesuatu yang disarankan oleh dokter. Dampak fisik akibat pengobatan yang dijalani di rumah sakit pernah membuat $\mathrm{OK}$ hampir menyerah akan pengobatannya, namun dukungan suami membuat $\mathrm{OK}$ kembali melanjutkan pengobatan. Dampak fisik (akibat kemoterapi) maupun psikologis (tertekan karena rasa sakit, kehilangan satu payudara, takut akan operasi) karena pengobatan di rumah sakit dihadapi OK dengan tahajud, berdoa, dan memperbanyak dzikir. Usaha $\mathrm{OK}$ dalam berobat medis juga didukung dengan sikap pasrah. OK meyakini bahwa Allah mendengar segala doa -doanya. Keberhasilan OK menghadapi masa tersulit tidak luput dari dukungan keluarga terutama suami. Selain antara $\mathrm{OK}$ dan sesama pasien kanker juga saling memberi dukungan secara psikologis.

\section{Tema 4 : Bersyukur karena merasa} dipermudah dalam segala hal

Saat ini OK masih harus mengkonsumsi obat meskipun perawatan di rumah sakit sudah selesai. Rangkaian pengobatan berupa kemoterapi dan radioterapi membawa perubahan pada kondisi OK. Secara fisik OK mudah merasa lelah dan tidak sekuat dahulu. Namun hal tersebut tetap disyukuri $\mathrm{OK}$ karena OK merasa Allah mempermudah segala urusan dan menolongnya dalam setiap permasalahn yang dihadapi. Rasa syukur ditunjukkan OK dengan lebih menjaga dan lebih peduli terhadap tubuh sendiri termasuk dalam urusan makan dan beraktivitas. OK mengungkapkan bahwa setelah rangkaian kemoetrapi selesai, intensitas $\mathrm{OK}$ dalam melakukan sholat 
tahajud menurun, namun OK tetap tidak meninggalkan aktivitas berdzikirnya.

\section{Responden YN}

Tema 3 : Yakin pada Allah dan beribadah dalam menghadapi penyakit kanker (berdoa dan berdzikir, serta melakukan tahajud meskipun tidak rutin)

Selama menjalani pengobatan kanker payudara di rumah sakit (kemoetrapi) YN merasakan dampak pengobatan baik secara fisik seperti muntah, rasa sakit yang amat sangat, lingkar mata, kuku, kulit menghitam, maupun dampak psikologis seperti mudah marah, stress, trauma, serta hampir putus asa. Selain itu YN harus tetap menyelesaikan tugas kantor diselasela kemoterapi. Berbagai dukungan baik keluarga, rekan kerja, maupun sesama pasien kanker membantu YN dalam menghadapi pengobatan dan sakit kanker payudara. YN juga lebih mendekatkan diri pada Allah dalam menghadapi kanker payudara seperti intensitas sholat tahajud yang meningkat dan juga memperpanjang waktu dzikir setelah sholat karena YN mulai merasakan kenikmatan saat berdzikir. Setelah kemoetrapi usai YN tidak melanjutkan pengobatan ke tahap radioterapi dan lebih memilih untuk merawat kanker payudara di rumah dengan menjaga makanan yang dikonsumsi serta dengan obat tradisional. YN memilih berpasrah dengan tetap berusaha sesuai kemampuan yang dimiliki. YN bersyukur karena sekarang dapat beraktivitas seperti sebelumnya meskipun tubuhnya mengalami perubahan seperti mudah lelah, tenaga berkurang, cepat berkeringat (mudah kepanasan), dan rentan sakit.

\section{Fase Pemaknaan Terhadap Sakit Responden DA}

Tema 6 : Sakit merupakan cobaan dan ganjaran atas hidup yang telah dijalani

DA menerima sakit kanker payudara sebagai suatu cobaan dari Allah. DA tidak menyalahkan Allah atas sakit ataupun merasa Allah tidak adil. Selain itu DA tidak berburuk sangka pada siapapun (seperti berpikiran bahwa kanker akibat disalahi orang). DA yakin bahwa amalan baik yang dilakukan akan dibalas oleh Allah meskipun sebelumnya DA pernah ragu akan hal itu. Keraguan tersebut tidak dirasakan lagi oleh DA, DA memilih meyakini bahwa sholawat, tahajud, serta doa-doa yang dipanjatkan akan dibalas oleh Allah dengan suatu kebaikan.

\section{Responden OK}

Tema 5 : Sakit merupakan ujian

Allah dan membawa lebih khusyuk dalam beribadah

Sakit kanker payudara dimaknai OK sebagai awal kedekatan dengan Allah. Setelah ada diagnosis kanker OK merasa lebih bisa untuk khusyuk saat berdoa dan lebih menikmati saat berdzikir. Kanker payudara dianggap OK sebagai 
suatu ujian dalam hidup yang diberikan Allah pada hambanya. OK mengungkapkan bahwa diirnya tidak perna $\mathrm{h}$ berpikir bahwa sakit yang dialami karena dibuat oleh orang lain yang justru hal itu membuahkan dosa. OK meyakini bahwa kesembuhan dapat diperoleh dengan ridho Allah, dan segala amal serta laku yang baik diyakini OK membawa keridhoan Allah.

\section{Responden YN}

Tema 4 : Kanker merupakan cobaan dan peringatan, bersyukur dapat mengetahui kanker lebih awal

YN menganggap kanker payudara sebagai cobaan dari Allah. YN menyadari bahwa kanker timbul sebab pola makan yang buruk dan semua sudah dengan campur tanga $\mathrm{n}$ Allah. YN pernah mendengar bahwa sakit kanker yang dialami sebab perbuatan orang lain, namun YN tidak terlalu percaya akan hal itu. YN mengambil hikmah atas sakitnya dan berusaha untuk selalu berpikir positif bahwa kanker payudara merupakan sebuah peringatan dari Allah dan manusia tetap akan mati baik dengan suatu penyakit ataupun tidak. YN bersyukur karena dapat mengetahui kanker payudaranya lebih awal sehingga dapat mempersiapkan diri lebih awal. Selain itu YN berusaha untuk menjadi lebih baik, kuat dalam ibadah, menata diri, dan membuat waktu yang tersisa menjadi lebih bermakna (berkualitas).

Jalaluddin (2012) menjelaskan bahwa dalam menghadapi musibah atau cobaan, orang yang memiliki keyakinan agama terlihat lebih tabah, dimana orang tersebut lebih mudah menetralisasi kegoncangan dan konflik yang terjadi dalam batin. Keyakinan dan kepercayaan pada Tuhan dijadikan sebagai pilihan tempat berlindung atau sebagai penyalur derita yang dirasakan. Tarakeshwar dkk (2006) juga menyebutkan bahwa praktek agama seperti berdoa dan meditasi dapat meningkatkan rasa kontrol terhadap kejadian yang penuh stress dimana agama memberikan rasa tujuan dan kebermaknaan untuk peristiwa yang tidak dapa $\mathrm{t}$ dipahami, tak terduga ataupun sakit kronis. Berdasarkan alasan inilah mengapa orang yang memiliki tekanan yang berat termasuk responden penelitian ini yang memiliki sakit kanker payudara menggunakan koping religius dalam menghadapi penyakitnya.

Selain sholat wajib 5 waktu, sholat tahajud juga dilakukan oleh ketiga responden dalam untuk mengurangi atau menghilangkan kecemasan, takut dan stress karena menghadapi penyakit kanker. Menurut Sholeh (2012) sholat tahajud yang dijalankan dengan penuh kesungguhan, khusyuk, ikhlas, dan rutin dapat menumbuhkan persepsi dan 
motivasi yang positif serta mengefektifkan coping. Respon berupa emosi yang positif dapat dapat menghindarkan reaksi stress. Selain sholat tahajud baik DA, OK, dan YN juga mengamalkan dzikir dalam kehidupan sehari-hari. Menurut Subandi (2009) ada banyak cara yang dilakukan untuk berdzikir misalnya dengan membaca kitab suci Al-Qur'an, menyebut nama Allah berulang-ulang baik Ismu Dzat ataupun Asma'ul Husna. Selain itu dzikir juga dapat dilakukan dengan membaca Sholawat, Istighfar, Takbir, Tasbih, Tahmid, Tahlil, dan membaca Hauqalah. Responden DA lebih berdzikir dengan membaca sholawat, sedangkan OK dan YN tidak mengkhususkan bacaan dzikirnya.

Al-Jauziyah (2002) bahwa dzikir yang diamalkan oleh seseorang akan membawa faedah diantaranya seperti menghadirkan ketenangan, menolong hamba dalam kesempitan, menjaga lidah dari perkataan yang dilarang, membuat hati selalu terjaga, mendekatkan kepada Allah, melembutkan hati, obat hati, menghilangkan rasa berat dan mempermudah yang susah, menghilangkan rasa takut dan menimbulkan ketenangan jiwa, memberikan kenikmatan yang tak tertandingi, dalam dzikir tersimpan kenimatan surga dunia, dzikir sebagai kekuatan kalbu dan kemuliaan jiwa, dzikir sebagai pintu menuju Allah. Sesuai dengan yang diungkapkan oleh AlJauziyah, DA merasakan banyak manfaat dari berdzikir sepeti kemudahan dan segala hal termasuk pekerjaan, $\mathrm{OK}$ merasa bahwa dzikir membawa perubahan emosi dan pikiran, dimana emosi lebih terjaga. Sedangkan YN merasakan manfaat dzikir berupa kepuasan dan sensasi yang berbeda dari melakukan dzikir.

Selain tahajud dan dzikir sikap pasrah dan berpikir postif juga ditunjukkan oleh ketiga responden. Jalaluddin (2012) menyatakan bahwa sikap pasrah akan menimbulkan perasaan positif pada seseorang seperti rasa senang, bahagia, puas, merasa dicintai dan merasa aman. Lalu Drajat (1982) mengungkapkan bahwa bagi orang yang beragama, kesulitan seberat apapun akan dihadapi dengan sabar karena keyakinan bahwa kesulitan dalam hidup merupakan bagian dari cobaan Allah pada hambaNya yang beriman. Tidak memandang kesulitan sebagai sesuatu yang negatif namun memandang bahwa dicelah kesulitan terdapat sebuah harapan. Selain itu orang yang beragama tidak akan menyalahkan orang lain atau mencari sebab negatif pada orang lain. Musbikin (2010) menjelaskan bahwa memandang kehidupan dengan sudut pandang positif meskipun dalam keadaan sakit 
menghasilkan ketenangan dan keyakinan kuat, sehingga akan timbul kesadaran bahwa sakit tak lain merupakan kehendak Allah yang Maha tahu, hikmah apa yang akan terjadi setelah itu dan jika Allah berkehendak Allah pula yang akan menyembuhkan.

\section{Dampak Koping Religius}

\section{Responden DA}

Tema 1 : Manfaat yang besar dari amalan yang dijalani

Responden DA merasakan bahwa amalan-amalan yang selama ini dijalani membawa kemanfaatan yang besar, terlebih untuk menghadapi dua peristiwa yang paling meyedihkan bagi DA yaitu kematian suami dan diagnosis kanker payudara. Rutinitas tahajud membawa ketenangan pada DA. Ketenangan pikiran dan hati serta kelegaan juga dirasakan DA saat berdzikir (membaca sholawat) dan berdoa pada Allah. DA merasakan bahwa dirinya dipermudah dalam segala urusan dengan rutin membaca sholawat. Selain itu, menurut anak DA (MJ) emosi DA sangat terkontrol dan tidak pernah marah. DA merupaka sosok yang tenang menurut MJ. Saat pikiran buntu, berwudhu merupakan langkah DA untuk menyegarkan dan menenangkan pikiran.

\section{Responden OK}

Tema 1 : Hati dan emosi terjaga dengan doa dan dzikir
Reponden OK mengatakan bahwa setelah diagnosis kanker payudara emosi OK lebih peka dan sensitif, maka dari itu OK mencoba untuk selalu menenangkan hatinya. Setelah didiagnosis kanker payudara, OK mulai membiasakan diri untuk bertahajud, berdzikir dan tidak lupa untuk selalu berdoa kepada Allah. OK mengatakan bahwa dzikir yang sering dilakukan membawa ketenangan. Selain itu OK lebih bisa mengontrol emosi (saat masih bekerja dan belum didiagnosis kanker payudara $\mathrm{OK}$ merupakan sosok yang mudah marah).

\section{Responden YN}

Tema 1 : Ibadah membawa ketenangan dan perasaan puas

Sedangkan pada responden YN, rasa sakit akibat pengobatan kanker payudara membuat YN lebih sensitif dan mudah marah. YN sangat menyadari perubahan emosinya saat sebelum dan saat menjalani proses pengobatan kanker kayudara. YN melakukan beberapa aktivitas yang bersifat religius seperti berdzikir, berdoa dan sholat tahajud untuk menetralkan hati dan agar lebih tenang. Meskipun tidak rutin melakukan sholat tahajud, YN merasakan manfaat dari amalan tersebut. Sebelumnya YN merasa tidak memiliki waktu untuk berdzikir setelah sholat magrib karena waktunya yang singkat, namun setelah diagnosis kanker YN mulai menikmati 
waktu dzikir selepas Maghrib dan merasakan sensasi yang berbeda, YN merasakan adanya kepuasan dengan berdzikir.

Ketiga responden baik DA, OK, maupun YN merasakan adanya ketenangan dan dampak positif lain dengan melakukan aktivitas religius seperti berdzikir, dan sholat tahajud dalam menghadapi kanker payudara. Musbikin (2010) menjelaskan bahwa tahajud mengandung aspek meditasi dan relaksasi karena sholat tahajud ini dilakukan di keheningan malam dan mengantar orang yang menunaikan lebih dekat dengan Allah. Hati yang dekat dengan Tuhan adalah hati yang damai. Pengalaman berdzikir yang dirasakan oleh setiap responden sesuai dengan yang diungkapkan oleh Al-Jauziyah (2002) bahwa dzikir akan membawa faedah diantaranya yaitu menghadirkan ketenangan, menolong hamba dalam kesempitan, membuat hati selalu terjaga, mendekatkan kepada Allah, melembutkan hati, obat hati, menghilangkan rasa berat dan mempermudah yang susah, menghilangkan rasa takut dan menimbulkan ketenangan jiwa, memberikan kenikmatan yang tak tertandingi, dalam dzikir tersimpan kenimatan surga dunia, dzikir sebagai kekuatan kalbu dan kemuliaan jiwa, serta dzikir sebagai pintu menuju Allah.
Faktor yang Mempengaruhi Koping

Religius

\section{Responden DA}

\section{Tema 1 : Orang disekitar yang membawa pengaruh dan memotivasi menuju lebih baik}

Sejak kecil orang tua DA terutama ibu sudah menanamkan ilmu agama dan rasa cinta pada aktivitas keagamaan seperti diajak oleh sang ibu untuk menghadiri acara pengajian- pengajian. Selain itu ibu DA juga sering memberikan nasehat -nasehat pada DA, dimana hal inilah yang menjadi contoh DA dalam mendidik anak-anak. Selain ibu, seorang Kyai yang menjadi idola DA juga menjadi sumber motivasi bagi DA dalam menjalankan amalan Sunnah seperti berbanyak-banyak membaca sholawat. Lalu guru agama DA juga memberikan motivasi untuk rutin menjalankan sholat tahajud agar hidup terasa tenang.

Tema 2 : Pengalaman batin atas penghayatan dari ritual keagamaan yang dijalani

Berbagai manfaat dan perasaan positif yang dirasakan DA saat menjalankan amalan ibadah (membaca sholawat, tahajud, berdoa) memperkuat DA untuk selalu menjalankan amalan tersebut apapun kondisinya Justru dengan adanya diagnosis kanker membuat DA semakin memperkuat ibadah 
yang dilakukan (namun untuk mendatangi pengajian, DA mulai jarang setelah kondisinya memburuk akibat kanker payudara yang dimiliki). DA mengatakan bahwa apabila ada yang tertinggal dari amalan rutin yang biasa dikerjakan, DA merasa tidak tenang dan ada yang kurang.

Tema 3 : Budaya berupa kegiatan keagamaan dari lingkungan sekitar

Kegiatan keagamaan seperti yasinan, dhiba'an, istighosyah, dan pengajian keagamaa $\mathrm{n}$ menjadi acara mingguan atau bulanan di desa DA. Hal tersebut tidak dapat dipisahkan dari kehidupan DA dan berpengaruh terhadap kehidupan religius DA. Setelah kanker payudara DA pecah, DA berhenti dan tidak menghadiri acaraacara tersebut karena kondisi kesehatan yang tidak mendukung, padahal sebelumnya DA tidak pernah melewatkan kegiatan-kegiatan tersebut.

\section{Responden OK}

Tema 1 : Orang terdekat sebagai penuntun menuju jalan Allah

Kehidupan religius $\mathrm{OK}$ mulai mengalami perubahan setelah menikah. Sebelum menikah OK termasuk orang yang jauh dari kehidupan religius. Setelah menikah OK dibimbing penuh oleh sang suami dalam urusan agama. Perubahan demi perubahan dirasakan oleh $\mathrm{OK}$ misalnya dalam hal sholat lima waktu, sebelum menikah hal tersebut sangat jarang dilakukan oleh OK.
Tema 2 : Keadaan sakit kanker dan kesadaran dari penghayatan atas

ibadah yang dilakukan

Tidak dipungkiri bahwa keadaan sakit kanker payudara menjadikan $\mathrm{OK}$ lebih tekun dalam beribadah. OK mengaku bahwa ibadah yang dilakukan terasa berbeda setelah adanya diagnosis kanker, dimana ada perasaan yang sebelumnya belum dirasakan oleh $\mathrm{OK}$ dalam beribadah. Hal tersebut memperkuat pikiran OK bahwa Allah merupakan satu-satunya penolong dalam menghadapi sakit kanker payudara.

\section{Responden YN}

Tema 1 : Ketertarikan belajar agama mulai muncul karena orang terdekat

Orang tua YN yang tidak terlalu banyak menanamkan ilmu agama sejak kecil menjadikan YN tidak terlalu paham akan ilmu agama. Namun hal tersebut mulai sedikit berubah saat YN SMA dan bertemu dengan bapak modin yang saat itu menjadi bapak kos YN. YN mulai belajar ilmu agama dari bapak modin tersebut dan beberapa pesan dari bapak modin tersebut masih dijalankan oleh YN sampai sekarang.

\section{Tema 2 : Penghayatan spiritual atas pengalaman dalam hidup}

Peristiwa kematian ayah YN merupakan pengalaman mendalam bagi YN, dimana YN mendapatkan dua 
pelajaran berharga dari peristiwa tersebut yaitu pentingnya keridhoan orang tua (ayah YN mengalami kesulitan saat sakaratul maut karena sering berbuat buruk pada sang ibu) dan Doa memiliki kekuatan yang luar biasa serta Allah maha besar atas segala sesuatu. Selain itu, penghayatan atas pengalaman perceraian kedua orang tua YN yang dulu pernah terjadi juga menjadi penguat pikiran dan hati YN dalam menhghadapi sakit kanker payudara bahwa rencana Allah merupakan sesuatu yang baik. Selain belajar dari pengalaman masa lalu, YN juga belajar banyak dari ceramah agama yang disampaikan baik di TV ataupun kegiatan keagamaan yang digelar mingguan atau bulanan di tempat kerja YN.

Rahayu (dalam Diana 2012) menjelaskan bahwa pengalaman merupakan salah satu faktor yang mempengaruhi koping yang dilakukan seseorang. Pengalaman yang dimaksudkan dalam penelitian ini adalah pengalaman batin atas ritual/amalan yang telah dilakukan. Hal tersebut terlihat dari responden DA dan YN. Selain pengalaman, pendidikan juga menjadi faktor yang mempengaruhi koping (rahayu dalam Diana, 2012). Pendidikan yang dimaksud dalam penelitian ini adalah pendidikan agama yang mempengaruhi koping religius seseorang. Pendidikan agama merupakan dasar bagi pembentuk jiwa keagamaan seseorang (Jalaluddin, 2012). Hal ini terlihat dari ketiga responden. Selain itu budaya setempat juga mempengaruhi koping (Rahayu dalam Diana, 2012). Menurut Koentjaraningrat (dalam Jalaluddin, 2012) kebudayaan ada dua bentuk yaitu bentuk kebudayaan dan isi kebudayaan. Kegiatan pengajian termasuk dalam bentuk kebudayaan yang berupa sistem sosial yaitu aktivitas, perilaku, upacara atau ritus yang konkret. Hal ini terlihat dari responden DA dan YN.

Pargament (dalam Diana, 2012) melihat bahwa orientasi religius yang umum berhubungan dengan koping yang spesifik terhadap suatu permasalahan hidup. Koping yang dilakukan oleh ketiga responden dipengaruhi oleh orientasi religius intrinsik. Baik DA, OK, maupun YN menganggap agama sebagai tujuan hidup, menghayati dan mengaplikasikan secara penuh ajaran agama.

Dukungan sosial juga mempengaruhi koping yang dilakukan oleh DA, OK, dan YN. Dukungan sosial tersebut didapat dari keluarga, teman ataupun tenaga medis. Menurut Mutadin (Dalam Muslimah \& Aliyah, 2013) dukungan sosial mempengaruhi strategi koping seseorang, dimana dukungan sosial ini meliputi dukungan pemenuhan kebutuhan emosi dan informasi. 


\section{DAFTAR PUSTAKA}

Al-Jauziyah, I.Q. (2002). Dzikir Cahaya Kehidupan. Jakarta : Gema insani Press

Damayanti, A.D., Fitriyah., \& Indriani. (2008). Penanganan Masalah Sosial dan Psikologis Pasien Kanker Stadium Lanjut dalam Perawatan Paliatif. Indonesian Journal Cancer, 1:30-34.

Diana, R. (2012). Psikologi Penyintas Bencana: Teori dan Aplikasi. Yogyakarta: Ash-Shaff. Drajat, Z. (1982). Peranan Agama dalam kesehatan Mental. Jakarta : PT. Inti Idayu Press.

Farcas, A.D., \& Nastasa, L.E. (2011). Coping in Patients with Hearts Failure. Bulletin of the Transilvania University of Brasov Series VII: Social Science, 4(53), 65-72.

Forshaw, M. (2009). Advanced Psychology: Health Psychology. London: Hodder \& Stoughton.

Jalaluddin. (2012). Psikologi Agama: Memahami Perilaku dengan Mengaplikasikan Prinsip - Prinsip Psikologi. Jakarta: PT. Rajagrafindo Persada.
Juniarly, A., \& Hadjam, M.N.R. (2012). Peran Koping Religius dan Kesejahteraan Subjektif Terhadap Stres pada Anggota Bintara Polisi di Polres Kebumen. Jurnal Psikologika, 17(1), 5-15.

Krok, D. The Mediating Role of Coping in the Relationships between religiousness and Mental Health. Archives of Psychiatry and Psychoterapy 2: 5-13

Manshaee, G., \& Amini, K. (2013). The Relationship between Spirituality with Emphasis on Religious Orientation and Psychosomatic Disorders (Asthma, Migraine, and Blood Pressure). Journal ProcediaSocial and Behavioral Sciences, 84: 1260-1264.

Musbikin, I. (2010). Terapi Shalat Tahajud Bagi Penyembuhan Kanker. Yogyakarta : Mitra Pustaka.

Mullimah, A.I., \& Aliyah, S. (2013). Tingkat Kecemasan dan Strategi Koping Religius Terhadap Penyesuaian Diri pada Pasien HIV/AIDS Klinik VCT RSUD Kota Bekasi. Jurnal Soul, 6(2), 43-68.

Oetami, F., Thaha, I.L.M., \& Wahidudin. (2014). Analisis Dampak Psikologis Pengobatan Kanker Payudara di RS 
Dr. Wahidin Sudirohusodo Kota Makasar.

Pargament, K., Koenig, H.G., \& Perez, L.M. (2000). The Many Methods of Religious Coping: Development and Initial Validation of the RCOPE. Journal of clinical psychology, 56(4), 519-543.

Pearce, M.J., Singer, J.L., \& Prigerson, H.G. (2006). Religious Coping among Caregivers of Terminally III Cancer Patients. Journal of Health Psychology, 11(5), 743-759

.Profil Kesehatan Provinsi D. I. Yogyakarta Tahun 2014 . (2015). Dinas Kesehatan Provinsi daerah Istimewa Yogyakarta.

Rice, V.H. (2011). Handbook of Stress, Coping, and Health: Implication For Nursing Research, Theory, and Practice. Sage Publication Inc.

Rinasti, F. (2012). Hubungan antara Tingkat Religiusitas dengan Subjective Well-Being (SWB) pada Remaja Awal. 1-12.

Safaria, T. (2011). Peran Religious Coping sebagai Moderator dari Job Insecurity terhadap Stres Kerja pada Staf Akademik. Jurnal Humanitas, 8(2), 156-166.
Sarafino, E., \& Smith, T.W. (2012). Health Psychology: Biopsychosocial Interactions. New York: John Wiley \& Sons.

Sholeh, M. (2012). Terapi Shalat Tahajud Menyembuhkan Berbagai Penyakit. Jakarta : Mizan Publika.

Simonic, B., \& Klobucar, N.R. (2016). Experiencing Positive Religious Coping in the Process of Divorce: A Qualitative study. Journal Relig Health. Subandi, MA. (2009). Psikologi Dzikir. Yogyakarta: Pustaka Pelajar.

Tarakeshwar, N., Vanderwerker, L.C., Paulk, E., Pearce, M.J., Kasl, S.V., dkk. (2006). Religious Coping is associated with the Quality of Life of Patients with Advance Cancer. Journal Palliative, 9(3), 646-657.

Taylor, S.E. (2006). Health Psychology. New York: McGrawHill.

Terapi Psikologis akan Membantu Penyembuhan Pasien Kanker. Diunduh pada 24 Mei 2016 dari www.Cancercenter.co.id/perawata n-kanker/perawatanpsikologis/4315.html.

Utami, M.S. (2012). Religiusitas, Koping Religius, dan Kesejahteraan 
Subjektif. Jurnal Psikologi, 39(1), 46-

66.

Widianti, E., Suryani., \& Puspasari D. (2014). Strategi Koping pada Pasien yang Baru Terdiagnosa Kanker. Jurnal Keperawatan.

Yenny, \& Herwana, E. (2006). Prevalensi Penyakit Kronis dan Kualitas Hidup pada Lanjut Usia di Jakarta Selatan. Jurnal Universa Medica, 25(4), 164171.

Zamanian, H., Ardebili, H.E., Ardebili, M.E., Shojaeizadeh, D., Nedjat, S., dkk. (2015). Religious Coping and Quality of Life in Women with Breast Cancer. Asian Pasific Journal of Cancer Prevention, 16: 7721-7724.

Zwingmann, C., Wirtz, M., Muller, C., Korber, J., Murken, S. (2006). Positive and Negative Religious Coping in German Breast Cancer Patients. Journal of Behavioral Medicine. 29(6), 533-547 